\title{
Clastogenicity of Piper cubeba (Piperaceae) seed extract in an in vivo mammalian cell system
}

\author{
Adriana Pereira Freire Junqueira ${ }^{1}$, Fabio Ferreira Perazzo ${ }^{2}$, Gustavo Henrique Bianco Souza ${ }^{3}$ \\ and Edson Luis Maistro ${ }^{1}$ \\ ${ }^{1}$ Departamento de Fonoaudiologia, Faculdade de Filosofia e Ciências, \\ Universidade Estadual Paulista, Marília, SP, Brazil. \\ ${ }^{2}$ Laboratório de Pesquisa em Fármacos, Universidade Federal do Amapá, Macapá, AP, Brazil. \\ ${ }^{3}$ Laboratório de Farmacognosia, Departamento de Farmácia, Universidade Federal de Ouro Preto, \\ Minas Gerais, Brazil.
}

\begin{abstract}
The plant Piper cubeba is widely distributed in tropical and subtropical regions and is used medically for various purposes but has not yet been evaluated for genotoxicity. We used male and female Swiss mice and Wistar rats and the comet assay and micronucleus test to investigate the mutagenic potential of a crude extract of $P$. cubeba seeds. The rodents were administered $0.5 \mathrm{~g} \mathrm{~kg}^{-1}, 1.0 \mathrm{~g} \mathrm{~kg}^{-1}$ and $1.5 \mathrm{~g} \mathrm{~kg}^{-1}$ of the extract by gavage. For the Swiss mice, peripheral blood was collected $24 \mathrm{~h}$ after treatment for the comet assay, and at 48 and $72 \mathrm{~h}$ for the micronucleus test. For the Wistar rats, peripheral blood and hepatic cells were collected for the comet assay and bone marrow cells were collected for the micronucleus test $24 \mathrm{~h}$ after treatment. At $1.5 \mathrm{~g} \mathrm{~kg}^{-1}$, the highest dose tested, the extract induced a statistically significant increase in both the mean number of micronucleated polychromatic erythrocytes and the level of DNA damage in the rodent cell types analyzed. Under our experimental conditions, the $P$. cubeba seed extract was genotoxic in vivo when administered orally to mice and rats.
\end{abstract}

Key words: micronucleus test, Piper cubeba, single cell gel electrophoresis (SCGE).

Received: October 10, 2006; Accepted: April 2, 2007.

\section{Introduction}

A number of natural products are used in the traditional medicine of many countries and alternative medicines for the treatment of various diseases are increasing in popularity. Many medicinal plants provide relief of symptoms comparable to that obtained by allopathic medicines. Therefore, an assessment of their genotoxic potential is necessary to ensure a relatively safe use of medicinal plants (Surh and Ferguson, 2003).

The genus Piper belongs to the family Piperaceae and has over 1000 species distributed in both hemispheres, where they grow in the form of erect or scadent (climbing) herbs, shrubs, or, less frequently, trees. Throughout the tropics, members of the genus Piper are used for many purposes, such as foods and spices, fish bait, fish poison, hallucinogens, insecticides, oils, ornaments, perfumes and for many

Send correspondence to Edson Luis Maistro. Departamento de Fonoaudiologia, Faculdade de Filosofia e Ciências, Universidade Estadual Paulista, Av. Hygino Muzzi Filho 737, Caixa Postal 181, 17525-900 Marília, SP, Brazil. E-mail: edson.maistro@marilia. unesp.br. medicines (Barrett, 1994; Joly 1981). The phytochemical profile of Piper species is characterized by the production of typical classes of compounds such as amides, benzoic acids, and chromenes, as well as terpenes, phenylpropanoids, lignans, other phenolics and a series of alkaloids (Jensen et al., 1993; Parmar et al., 1997; Wu et al., 1997).

The species Piper cubeba L., known in Brazil as "pimenta de Java" ("Java pepper") and in English as Cubeb pepper, is a popular medicinal plant which has been extensively used in Europe since the Middle Ages, as well as in many other countries, including Arabia, India, Indonesia and Morocco. The fruits are used as a spice and have also been used for the treatment of abdominal pain, asthma, diarrhea, dysentery, gonorrhea, enteritis and syphilis (Eisai, 1995; Sastroamidjojo, 1997) and has also been reported to have an inhibitory effect on hepatitis $\mathrm{C}$ virus protease (Januario et al., 2002). Choi and Hwang (2003) demonstrated significant anti-inflammatory and analgesic activities of the methanolic extract from fruits of $P$. cubeba.

In view of the potential therapeutic use of $P$. cubeba extracts and the absence of any data on its genetic toxicity in eukaryotes, the study described in this paper was under- 
taken to evaluate the potential in vivo mutagenic effects of $P$. cubeba seed extract in terms of DNA damage in hepatic and peripheral blood leukocytes and the induction of micronuclei in bone marrow polychromatic erythrocytes of rodents.

\section{Material and Methods}

\section{Plant material}

Seeds of Piper cubeba L. were imported from India country, air-dried to constant weight at $55^{\circ} \mathrm{C}$ and powdered. A simple extract was made by macerating $150 \mathrm{~g}$ of powdered seeds in three litres of a $70 \%(w / v)$ ethanol in water mixture for $48 \mathrm{~h}$, after which the macerate was filtered and a further $150 \mathrm{~g}$ of seed powder was added to the filtrate and macerated for a further $48 \mathrm{~h}$ to produce a crude ethanolic aqueous extract which was concentrated under reduced pressure to produce $54 \mathrm{~g}$ of crude extract (yield $18 \%)$.

\section{Animals and assay procedures}

We used 25-30g twelve-week old Swiss mice (Mus musculus) and $100 \mathrm{~g}$ six-week old Wistar rats (Rattus norvegicus) obtained from the of Jose do Rosario Vellano University, Alfenas town, Brazil, animal house. The rodents were housed in polyethylene cages $(n=6)$ in a climate-controlled environment $\left(25 \pm 4{ }^{\circ} \mathrm{C}, 55 \pm 5 \%\right.$ humidity) with a $12 \mathrm{~h}$ (07:00 to 19:00) day length and had ad libitum access to food (Labina, Purina) and water.

The rats and mice were divided into negative control, extract and positive control experimental groups, each containing three females and three males housed as described above. The $P$. cubeba seed extract was administered by gavage at concentrations of $0.5 \mathrm{~g} \mathrm{~kg}^{-1}, 1 \mathrm{~g} \mathrm{~kg}^{-1}$ and $1.5 \mathrm{~g} \mathrm{~kg}^{-1}$ in single $0.5 \mathrm{~mL}$ doses, these concentrations being chosen based on a $P$. cubeba seed extract $50 \%$ lethal dose $\left(\mathrm{LD}_{50}\right)$ value of $2 \mathrm{~g} \mathrm{~kg}^{-1}$ for Swiss mice (Perazzo F.F., data not shown). The negative control groups (both mice and rats) received distilled water by the same route. The positive control group for mice received $0.05 \mathrm{~g} \mathrm{~kg}^{-1}$ of N-nitrosoN-ethylurea (ENU, Chemical Abstracts Service (CAS) No. 759-73-9, Sigma) dissolved in $\mathrm{pH} 6$ phosphate-buffer while the positive control group for rats received $0.05 \mathrm{~g}$ of cyclophosphamide (CP, CAS: C 0768, Sigma) $\mathrm{kg}^{-1}$ dissolved in the saline solution $(\mathrm{NaCl} 0.9 \%)$, intraperitoneal injections being administered in both cases.

The comet assay was carried out by the method described by Speit and Hartmann (1999), which is based on the original work of Singh et al. (1988) and includes modifications introduced by Klaude et al. (1996) as well as additional modifications. Mouse peripheral blood leukocytes and rat peripheral blood leukocytes and liver cells were sampled $24 \mathrm{~h}$ after treatment. Liver samples were washed in saline solution in an ice bath and a fragment transferred to a Petri dish containing $1 \mathrm{~mL}$ of Hank's solution (pH 7.5) and then gently homogenized with small forceps. A $10 \mu \mathrm{L}$ aliquot of cells from each animal was mixed with $120 \mu \mathrm{L}$ of $0.5 \%(\mathrm{w} / \mathrm{v})$ low melting point agarose (Invitrogen, Cat. No. $15517-014)$ at $37^{\circ} \mathrm{C}$ and the mixture rapidly spread onto microscope slides pre-coated with $1.5 \%$ normal melting point agarose (Invitrogen,. Cat. No. 15510-019). Coverslips were added and the slides were allowed to gel at $4{ }^{\circ} \mathrm{C}$ for $20 \mathrm{~min}$. The coverslips were gently removed and the slides were then immersed in cold, freshly prepared lysing solution consisting of $89 \mathrm{~mL}$ of a stock solution $(2.5 \mathrm{M}$ $\mathrm{NaCl}, 100 \mathrm{mM}$ ethylenediaminetetraacetic acid (EDTA, Merk), $10 \mathrm{mM}$ Tris, $\mathrm{pH}$ set to 10 with $\sim 8 \mathrm{~g} \mathrm{NaOH}, 890 \mathrm{~mL}$ of distilled water and $1 \%(\mathrm{w} / \mathrm{v})$ sodium N-lauroylsarcosine (Sigma, L-5125)), plus $1 \mathrm{~mL}$ of Triton X-100 (Merck) and $10 \mathrm{~mL}$ of DMSO. The slides, which were protected from light, were left to stand at $4{ }^{\circ} \mathrm{C}$ for $1 \mathrm{~h}$ and then placed in the gel box, positioned at the anode end, and left in a high $\mathrm{pH}$ $(>13)$ electrophoresis buffer $(300 \mathrm{mM} \mathrm{NaOH}$ per $1 \mathrm{mM}$ EDTA, prepared from a stock solution of $10 \mathrm{~N} \mathrm{NaOH}$ and $200 \mathrm{mM}, \mathrm{pH} 10 \mathrm{EDTA}$ ) at $4{ }^{\circ} \mathrm{C}$ for $20 \mathrm{~min}$ prior to electrophoresis, to allow the DNA to unwind. The electrophoresis run was carried out at $4{ }^{\circ} \mathrm{C}$ in an ice bath for $20 \mathrm{~min}$ at $1.25 \mathrm{~V} \mathrm{~cm}^{-1}$ and $300 \mathrm{~mA}$. The slides were then submerged in a neutralization buffer $(0.4 \mathrm{M}$ Tris- $\mathrm{HCl}, \mathrm{pH} 7.5)$ for $15 \mathrm{~min}$, dried at room temperature, fixed in $100 \%$ ethyl alcohol for $10 \mathrm{~min}$, dried and stored overnight or longer. For staining, the slides were briefly rinsed in distilled water, covered with $30 \mu \mathrm{L}$ of $1 \mathrm{x}$ ethidium bromide staining solution prepared from a 10x stock $\left(200 \mu \mathrm{g} \mathrm{mL}^{-1}\right)$ and covered with a coverslip. The stained cells were evaluated immediately at $400 \mathrm{x}$ magnification using a Nikon fluorescence microscope with a $515 \mathrm{~nm}$ to $560 \mathrm{~nm}$ excitation filter and a $590 \mathrm{~nm}$ barrier filter. The animals used in this study were sacrificed by cervical dislocation. The Animal Bioethical Committee of the UNIFENAS, Brazil, approved the present study on October 25, 2005 (protocol number $15 \mathrm{~A} / 2005$ ), in accordance with the Federal Government legislation on animal care.

For the micronucleus assay we collected peripheral blood from the orbital vein of each mouse $48 \mathrm{~h}$ and $72 \mathrm{~h}$ after treatment and prepared blood-smear slides, while the rats were sacrificed $24 \mathrm{~h}$ after treatment and the bone marrow cells from one femur prepared as recommended by Schmid (1976). All the slides were coded, fixed with methanol and stained with Giemsa solution. Two thousand polychromatic erythrocytes from each rat, and four thousand polychromatic erythrocytes from each mouse (2000 cells from the $48 \mathrm{~h}$ blood sample and 2000 cells from the $72 \mathrm{~h}$ blood sample), were scored. In rats, one thousand cells were analyzed per animal to determine the polychromatic/normochromatic erythrocyte ratio (PCE:NCE).

\section{Scoring procedures and statistical analysis}

The extent and distribution of DNA damage indicated by the comet assay was evaluated by examining at least 100 
randomly selected and non-overlapping cells on the slides per animal. These cells were visually scored into comet classes according to tail size: class $0=$ no tail; class $1=$ tail shorter than the diameter of the head (nucleus); class $2=$ tail length 1 to $2 \mathrm{x}$ the diameter of the head; and class $3=$ tail longer than $2 \mathrm{x}$ the diameter of the head. Comets with no heads and those with nearly all the DNA in the tail, or with a very wide tail, were excluded from the evaluation because they probably represented dead cells (Hartmann and Speit, 1997). The total score for 100 comets was obtained by multiplying the number of cells in each class by the damage class, ranging from 0 (all undamaged) to 300 (all maximally damaged).

The micronucleus test and comet assay data were submitted to one-way analysis of variance test (ANOVA) and the Tukey-Kramer multiple comparison test (Sokal and Rohlf, 1995), using the GraphPad Instat ${ }^{\circledR}$ program version 3.01. The results were considered statistically significant at $\mathrm{p}<0.05$.

\section{Results and Discussion}

The comet assay is a sensitive, reliable and rapid method for the detection of double- and single-strand DNA breaks, alkali-labile sites and delayed repair sites in individual eukaryotic cells, and is an important tool for evaluating the in vitro and in vivo genotoxic potential of compounds (Rojas et al., 1999; Tice et al., 2000; Sekihashi et al., 2002). Our comet assay results are shown in Tables 1, 2 and 3, where the female and male results for the different concentrations of extract and the N-nitroso-N-ethylurea (ENU) and cyclophosphamide (CP) positive controls are compared with the negative control (water). As expected, when the positive controls were compared to the negative controls we found that both ENU and CP induced a statistically significant increase ( $p<0.05$ or greater) in comet assay DNA migration for mouse and rat leukocytes and rat liver cells (Tables 1, 2, 3). Regarding the Piper cubeba extracts, we found a statistically significant increase in DNA migration at an extract concentration of $1 \mathrm{~g} \mathrm{~kg}^{-1}$ ( $50 \%$ of the $\mathrm{LD}_{50}$ value) for leukocytes from male $(\mathrm{p}<0.05)$ rats (Table 2) and at $1.5 \mathrm{~g} \mathrm{~kg}^{-1}\left(75 \%\right.$ of the $\left.\mathrm{LD}_{50}\right)$ for leukocytes from the female mice $(\mathrm{p}<0.05$, Table 1$)$ and female $(\mathrm{p}<0.001)$ and male $(\mathrm{p}<0.05)$ rats (Table 2$)$. Rat liver cells also showed a statistically significant increase $(p<0.001$ for females, $\mathrm{p}<0.05$ for males) in DNA damage at an extract concentration of $1.5 \mathrm{~g} \mathrm{~kg}^{-1}$ compared to the negative control (Table 3). At extract concentrations that induced a significant increase in DNA damage, the majority of the damaged cells showed minor damage (class 1) and with very few showed a large amount of damage (class 2 and 3 ).

The mouse micronucleus assay has been used to evaluate aneuploidy and clastogenic chromosome aberrations (Morita et al., 1997), but experiments using erythrocytes from mammalian species other than mice (e.g. humans, laboratory rats and wild rodents) have met with less success due to the ability of the spleen to remove micronucleated (MN) erythrocytes from the blood (Simula and Priestly, 1992; Holden et al., 1997).

The results for our mouse micronucleus assay evaluation of the clastogenic potential of $P$. cubeba seed extract are given in Table 4, which shows that, as compared to the negative control (water), there was a statistically significant increase $(\mathrm{p}<0.001)$ in the mean number of micronucleated polychromatic erythrocytes (MNPCEs) in blood sampled at 48 and $72 \mathrm{~h}$ for the $1.0 \mathrm{~g} \mathrm{~kg}^{-1}$ and $1.5 \mathrm{~g} \mathrm{~kg}^{-1}$ doses of extract and, as expected, $50 \mathrm{mg} \mathrm{kg}^{-1}$ ENU positive control.

The rat bone marrow cell micronucleus assay results are summarized in Table 5, which shows that, as compared to the negative control, there was a statistically significant increase in the average number of MNPCEs in rats treated with $1.0 \mathrm{~g} \mathrm{~kg}^{-1}(\mathrm{p}<0.05)$ and $1.5 \mathrm{~g} \mathrm{~kg}^{-1}(\mathrm{p}<0.01)$ of extract and, as expected, the positive CP control $(p<0.01)$.

However, the ratio of polychromatic erythrocytes to normochromatic erythrocytes (PCE:NEC, Table 5) from $\mathrm{CP}$ and extract treated groups was not significantly different from the negative control group $(\mathrm{p}>0.05)$, indicating that the $P$. cubeba seeds extract did not present cytotoxic properties in rat bone marrow cells at any of the doses tested.

Phytochemical screening of $P$. cubeba extracts has detected alkaloids/amides, lignans, neolignans and terpenes, including aschantin, dihydrocubebin, piperine alkaloid, piperol A, B and C, piperol A-triacetate, the terpenes $\alpha$-copaene, $\rho$-cymene, germacrene $\mathrm{D}$ and limonene (among others), sesamin and (+)-Zeylinol (Parmar et al., 1997). In a more recent review, Usia et al. (2005) reported sixteen known compounds ( $\alpha$-asarone, (-)-clusin, (-)-dihydroclusin, ethoxyclusin, (-)-cubebin, (-)-cubebinin, (-)-cubebininolide, (-)-dihydrocubebin, $\alpha$-methylcubebin, (-)-hinokinin, magnosalin, medioresinol, 2,4,5-trimetoxiphenylacetone, 1-(2,4,5-trimetoxyphenyl)-1,2-propanedione, (-)-thujaplicatin trimethyl ether, (-)-yatein), two new lignans ((8R,8'R)-4-hydroxycubebinone and (8R, 8'R,9'S)-5-methoxyclusin) and two new sesquiterpenes

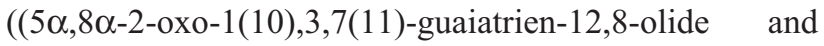
$(1 \alpha, 2 \beta, 5 \alpha, 8 \alpha, 10 \alpha)-1,10$-epoxy-2-hydroxy-3,7(11)-guaiad ien-12,8-olide).

Insecticidal properties have been reported for the Piper species $P$, guineense, $P$. brachystachyum and $P$. nigrum (Jacobson and Crosby, 1971; Parmar et al., 1997; Jensen et al., 2006), and some compounds present in $P$. cubeba seed extract (aschantin, $\alpha$-copaene, $\rho$-cymene, dihydrocubebin, germacrene $\mathrm{D}$, lignans, limonene and sesamin) are also present in $P$. guineense seeds (Parmar et al., 1997). Since several insecticides are known to have mutagenic effects (Jha et al., 2002; Beard, 2006), the clastogenic effects of the $P$. cubeba seed extract observed in the present work could be attributed to some compound with insecticide potential. We intend to investigate some isolated com- 


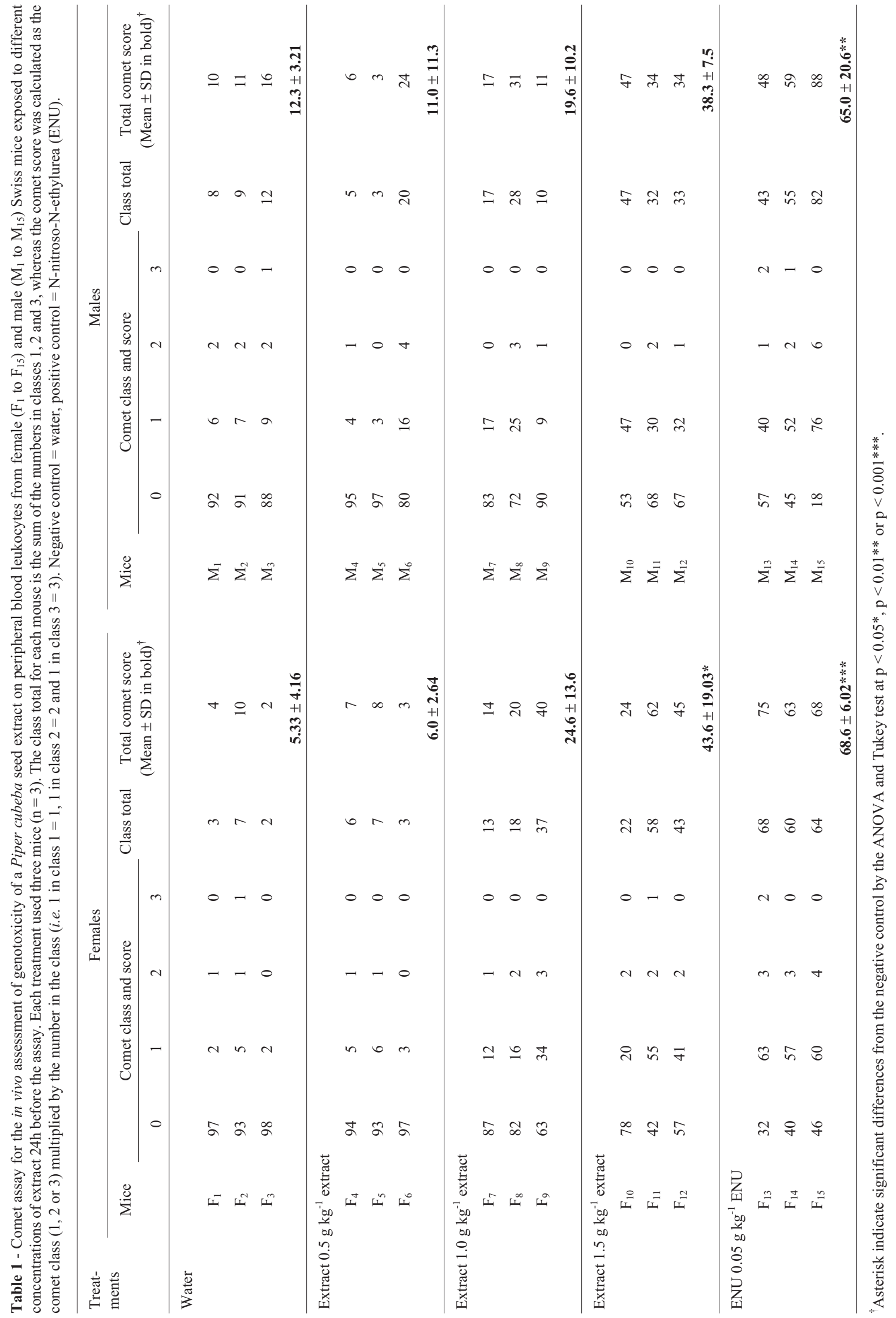




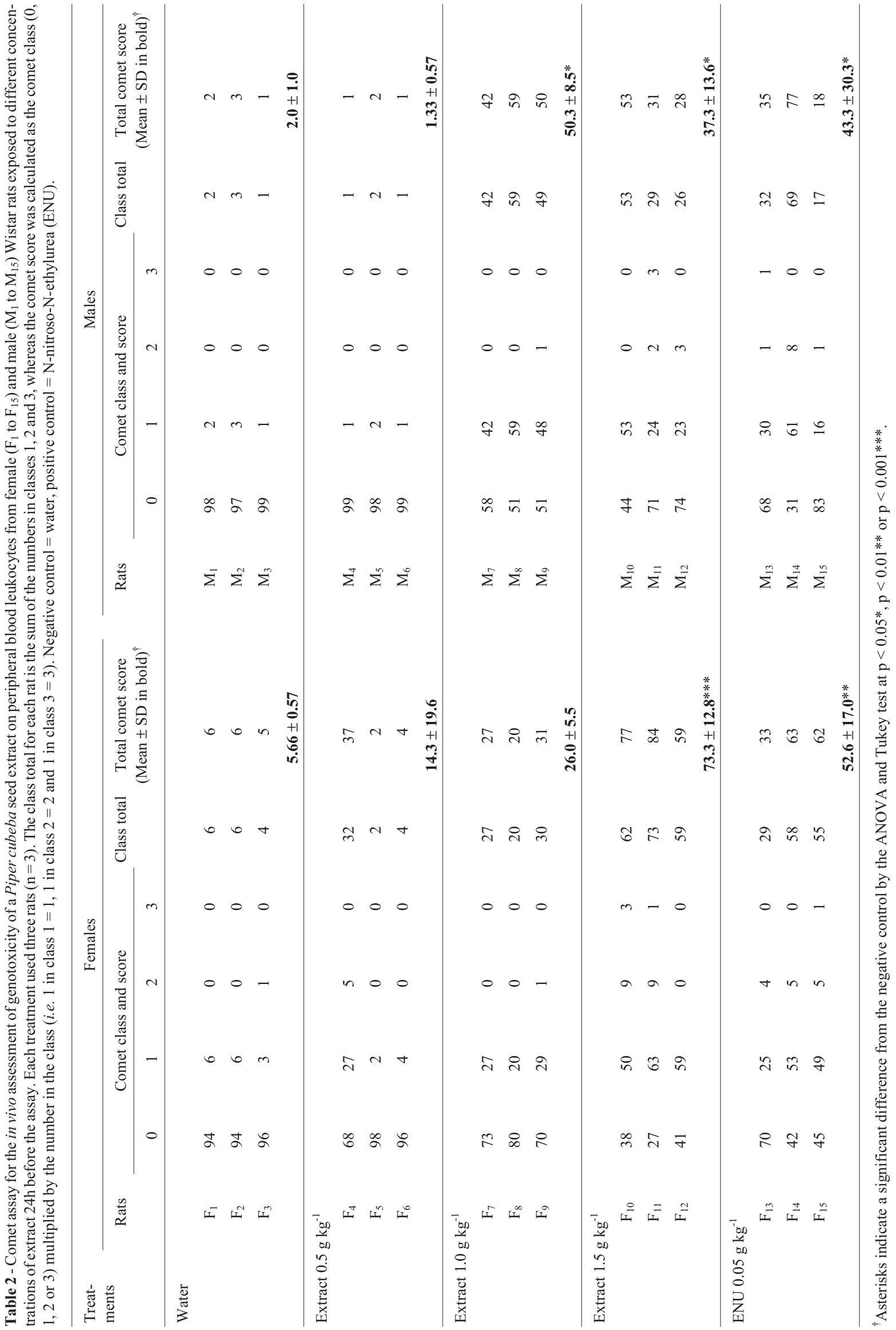




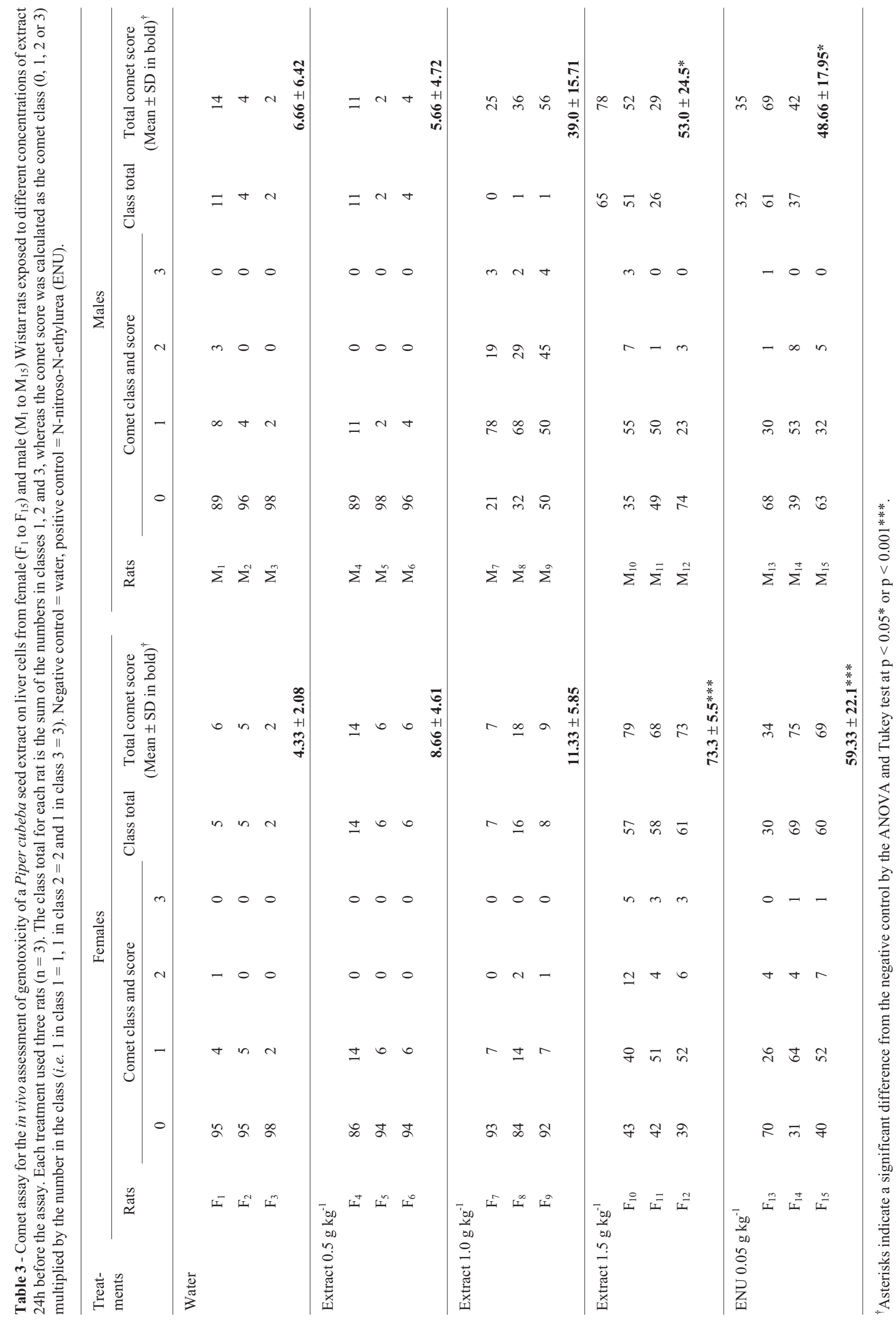


Table 4 - Micronucleus (MN) test results showing the number of micronucleated polychromatic erythrocytes (MNPCEs) in peripheral blood samples from female $\left(n=3 ; F_{1}, F_{2}\right.$ and $\left.F_{3}\right)$ and male $\left(n=3 ; M_{1}, M_{2}\right.$ and $\left.M_{3}\right)$ Swiss mice treated with a Piper cubeba seed extract. For each blood collection time 2000 cells were scored per mouse. $\mathrm{SD}=$ standard deviation. Negative control = water, positive control = N-nitroso-N-ethylurea (ENU).

\begin{tabular}{|c|c|c|c|c|c|c|c|c|}
\hline \multirow[t]{2}{*}{ Treatments } & \multirow{2}{*}{$\begin{array}{l}\text { Blood collection } \\
\text { time (h) }\end{array}$} & \multicolumn{6}{|c|}{ Number of MNPCEs per mouse } & \multirow{2}{*}{$\begin{array}{c}\text { Mean number } \\
\text { of MNPCEs }( \pm \mathrm{SD})\end{array}$} \\
\hline & & $\mathrm{F}_{1}$ & $\mathrm{~F}_{2}$ & $\mathrm{~F}_{3}$ & $\mathrm{M}_{1}$ & $\mathrm{M}_{2}$ & $\mathrm{M}_{3}$ & \\
\hline \multirow[t]{2}{*}{ Water } & 48 & 1 & 2 & 3 & 1 & 2 & 2 & $1.83 \pm 0.75$ \\
\hline & 72 & 1 & 3 & 2 & 2 & 2 & 1 & $1.83 \pm 0.75$ \\
\hline \multirow[t]{2}{*}{ Extract $0.5 \mathrm{~g} \mathrm{~kg}^{-1}$} & 48 & 4 & 6 & 5 & 6 & 0 & 4 & $4.16 \pm 2.22$ \\
\hline & 72 & 4 & 5 & 5 & 4 & 6 & 2 & $4.33 \pm 1.36$ \\
\hline \multirow[t]{2}{*}{ Extract $1.0 \mathrm{~g} \mathrm{~kg}^{-1}$} & 48 & 9 & 5 & 7 & 7 & 8 & 4 & $6.66 \pm 1.86^{*}$ \\
\hline & 72 & 8 & 11 & 6 & 4 & 8 & 7 & $7.33 \pm 2.33 *$ \\
\hline \multirow[t]{2}{*}{ Extract $1.5 \mathrm{~g} \mathrm{~kg}^{-1}$} & 48 & 5 & 8 & 6 & 6 & 7 & 7 & $6.50 \pm 1.04^{*}$ \\
\hline & 72 & 7 & 6 & 6 & 7 & 7 & 7 & $6.66 \pm 0.51^{*}$ \\
\hline \multirow[t]{2}{*}{ ENU $0.05 \mathrm{~g} \mathrm{~kg}^{-1}$} & 48 & 10 & 9 & 8 & 8 & 7 & 7 & $8.16 \pm 1.16^{*}$ \\
\hline & 72 & 9 & 8 & 9 & 8 & 9 & 7 & $8.33 \pm 0.81^{*}$ \\
\hline
\end{tabular}

*Significantly different from negative control by the ANOVA and Tukey test at $\mathrm{p}<0.05$.

Table 5 - Micronucleus (MN) test results showing the number of micronucleated polychromatic erythrocytes (MNPCE) bone-marrow samples from female $\left(n=3 ; F_{1}, F_{2}\right.$ and $\left.F_{3}\right)$ and male $\left(n=3 ; M_{1}, M_{2}\right.$ and $\left.M_{3}\right)$ Wistar rats treated with Piper cubeba seed extract, 2000 cells being scored per rat. The ratio of polychromatic erythrocytes to normochromatic erythrocytes (PCE:NCE) was also calculated, 1000 cells being scored per rat. SD $=$ standard deviation. Negative control $=$ water, positive control $=$ cyclophosphamide $(\mathrm{CP})$.

\begin{tabular}{lcccccccc}
\hline Treatments & \multicolumn{9}{c}{ Number of MNPCE per rat } & MNPCE & \multirow{2}{*}{$\begin{array}{c}\text { PCE:NCE } \\
\text { (Mean } \pm \text { SD) }\end{array}$} \\
\cline { 2 - 5 } & $\mathrm{F}_{1}$ & $\mathrm{~F}_{2}$ & $\mathrm{~F}_{3}$ & $\mathrm{M}_{1}$ & $\mathrm{M}_{2}$ & $\mathrm{M}_{3}$ & & \\
Water & 2 & 1 & 3 & 4 & 0 & 1 & $1.83 \pm 1.47$ & $0.84 \pm 0.07$ \\
Extract $0.5 \mathrm{~g} \mathrm{~kg}^{-1}$ & 3 & 1 & 2 & 1 & 1 & 3 & $1.83 \pm 0.98$ & $0.78 \pm 0.10$ \\
Extract $1.0 \mathrm{~g} \mathrm{~kg}^{-1}$ & 6 & 4 & 7 & 5 & 5 & 6 & $5.5 \pm 1.04 *$ & $0.84 \pm 0.07$ \\
Extract $1.5 \mathrm{~g} \mathrm{~kg}^{-1}$ & 8 & 3 & 7 & 5 & 5 & 9 & $6.16 \pm 2.22^{* *}$ & $0.78 \pm 0.05$ \\
CP $0.05 \mathrm{~g} \mathrm{~kg}^{-1}$ & 8 & 5 & 1 & 9 & 8 & 7 & $6.33 \pm 2.94 * *$ & $0.75 \pm 0.05$ \\
\hline
\end{tabular}

${ }^{\dagger}$ Asterisks indicate significant differences from the negative control by the ANOVA and Tukey test at $\mathrm{p}<0.05^{*}$ or $\mathrm{p}<0.01 * *$.

pounds from $P$. cubeba seed extract to verify this hypothesis.

To our knowledge, this is the first report of the mutagenic effect of $P$. cubeba extract on Swiss mice and Wistar rat cells. Our results indicate that when given at high doses of $1.0 \mathrm{~g} \mathrm{~kg}^{-1}$ and $1.5 \mathrm{~g} \mathrm{~kg}^{-1}$ P. cubeba extract induced a significant increase in the mean number of cells with DNA damage and micronuclei, indicating that the extract, or its metabolites, show moderate genetic toxicity in rodent cells and that caution is required regarding the indiscriminate use of high dose $P$. cubeba extracts by the public.

\section{Acknowledgments}

This investigation was supported by The Brazilian agencies FAPEMIG (Rede Mineira de Ensaios Toxicológicos e Farmacológicos de Produtos Terapêuticos, EDT 1879/02) and the Brazilian National Counsel of Technological and Scientific Development (Conselho Nacional de
Desenvolvimento Científico e Tecnológico, CNPq) process number 306544/2006-7.

\section{References}

Barrett B (1994) Medicinal plants of Nicaragua's Atlantic Coast. Economic Botany 481:8-20.

Beard J (2006) DDT and human health. Sci Total Environ. 355:78-89.

Choi EM and Hwang JK (2003) Investigations of anti-inflammatory and antinociceptive activities of Piper cubeba, Physalis angulata and Rosa hybrida. Journal of Ethnopharmacology 89:171-175.

Eisai PT (1995) Medicinal Herb Index in Indonesia. $2^{\text {nd }}$ edition. Dian Rakyat, Jakarta, 21 pp.

Hartmann A and Speit G (1997) The contribution of cytotoxicity to DNA-effects in the single cell gel test (comet assay). Toxicol Lett 90:183-188.

Holden, HE, Majeska JB and Studwell D (1997) A direct comparison of mouse and rat bone marrow and blood as target tissues in the micronucleus assay. Mutat Res 391:87-89. 
Jacobson M and Crosby DG (1971) Naturally Occurring Insecticides. Marcel Dekker, New York, 585 pp.

Januario AH, Rodrigues Filho R, Pietro RCLR, Kashima S, Sato DN and Franca SC (2002) Antimycobacterial physalins from Physalis angulata L. (Solanaceae). Phytotherapy Research 16:445-448.

Jensen S, Hansen J and Boll PM (1993) Lignans and neolignans from Piperaceae (Review). Phytochemistry 33:523-530.

Jensen HR, Scott IM, Sims S, Trudeau VL and Arnason JT (2006) Gene expression profiles of Drosophila melanogaster exposed to an insecticidal extract of Piper nigrum. J Agric Food Chem 54:1289-1295.

Jha AM, Singh AC and Bharti MK (2002) Clastogenicity of carbazole in mouse bone marrow cells in vivo. Mutat Res 521:11-17.

Joly LG (1981) Feeding and trapping fish with Piper auritum. Econ Bot 35:383-390.

Morita T, Asano N, Awogi T, Sasaki YF, Sato S, Shimada H, Sutou S, Suzuli T, Wakata A, Sofuni T, et al. (1997) Evaluation of the rodent micronucleus assay in the screening of IARC carcinogens (Group 1.2A and 2B). The summary report of the $6^{\text {th }}$ collaborative study by CSGMT/JEMS MMS. Mutat Res 389:3-122.

Parmar VS, Jain SC, Bisht KS, Jain R, Taneja P, Jha A, Tyagi OD, Prasad AK, Wengel J, Olsen CE, et al. (1997) Phytochemistry of the genus Piper. Phytochemistry 46:597-673.

Rojas E, Lopez MC and Valverde M (1999) Single cell gel electrophoresis assay: Methodology and applications. J Chromatography B 722:225-254.

Sastroamidjojo S (1997) Obat Asli. Dian Rakyat, Jakarta, pp 149.

Schmid W (1976) The micronucleus test for cytogenetic analysis. In: Hollaender A (ed) Chemical Mutagenesis, Principles and
Methods for their Detection. v. 4. Plenum Press, New York, pp 31-53.

Sekihashi K, Yamamoto A, Matsumura Y, Ueno S, WatanabeAkanuma M, Kassie F, Knasmuller S, Tsuda S and Sasaki YF (2002) Comparative investigation of multiple organs of mice and rats in the comet assay. Mutat Res 517:53-74.

Simula AP and Priestly BG (1992) Species differences in the genotoxicity of cyclophosphamide and styrene in three in vivo assays. Mutat Res 271:49-58.

Singh NP, McCoy MT, Tice RR and Schneider EL (1988) A simple technique for quantitation of low levels of DNA damage in individual cells. Exp Cell Res 175:184-191.

Sokal RR and Rohlf FJ (1995) Biometry. In: Freeman WH (ed) Biometry: The principles and practice of statistics in biological research. P. Imprenta, San Francisco, pp. 175-205.

Speit G and Hartmann A (1999) The comet assay (single-cell gel test). In: Henderson DS (ed) Methods in Molecular Biology. v. 113, DNA Repair Protocols: Eukaryotic Systems. Humana Press Inc., Totowa, pp 203-212.

Surh Y and Ferguson LR (2003) Dietary and medicinal antimutagens and anticarcinogens: Molecular mechanisms and chemopreventive potential - Highlights of a symposium. Mutat Res 523-524:1-8.

Tice RR, Agurell E, Anderson D, Burlinson B, Hartmann A, Kobayashi H, Miyamae Y, Rojas E, Ryu JC and Sasaki YF (2000) Single cell gel/comet assay: Guidelines for in vitro and in vivo genetic toxicology testing. Environmental and Molecular Mutagenesis 35:206-221.

Usia T, Watabe T, Kadota S and Tezuka Y (2005) Potent CYP3A4 inhibitory constituents of Piper cubeba. J Nat Prod 68:6468.

Wu Q, Wang S, Tu G, Feng Y and Yang J (1997) Alkaloids from Piper puberullum. Phytochemistry 44:727-730.

Associate Editor: Catarina S. Takahashi 